\section{How animals work}

Summarize yourself in the form of a title of a paper in Nature.

Cool curiosity surviving despite frigid environment.

What was your first experiment as a child? Collecting all kinds of insects, in particular chrysalises to watch butterflies blossom out, and beetles. One evening my father brought home a hornet he had captured in his coat. The hornet escaped, causing panic. As a result, my mother didn't like entering my room, which was quite a zoo.

Who has been the most important mentor in your career?

My first mentor was Jean Dorst, author of Avant que Nature Meure. When I was 15, I wrote to him about my dream to become an ornithologist. His reply emphasized the difficulty of making a living at it, but he encouraged my passion for fieldwork, while understanding my dissatisfaction with an academic science that I wished would be less descriptive.

Whose graduate student would you most like to have been?

Charles Darwin, when he was working in the Galapagos, to help him label his samples properly.

What single scientific paper or talk changed your career path?

'Animal anorexias' (N. Mrosovsky and D. F. Sherry Science 207, 837-842; 1980) showed that top science can be achieved with good questions and very simple measurements. This paper was also stimulating at a difficult time, when a scientific director of the CNRS told the community that 'physiology' had become meaningless as a field.

What book has been most influential in your scientific career?

Reading How Animals Work by Knut SchmidtNielsen (Cambridge University Press, 1972), I understood I had found the direction I was searching for. Not long after, I had the privilege of working in his lab. A master and my mentor in the understanding of function in nature, he also taught me how to say what is interesting in words that are accessible to a large audience.

What gives you the most job satisfaction now? What are your major frustrations?

The most satisfaction comes at the time an interesting question is unravelled, and also when students or postdocs have their work accepted for publication or obtain a good position. Frustration comes with the continual increase in both scientific bureaucracy and the complexity of accounting.
What book is currently on your bedside table? La Tapisserie de Bayeux (Editions du Zodiaque, 2002) by Lucien Musset from the University of Caen. He presents a new approach to this 65-metre tapestry that illustrates the turbulent accession of William Duke of Normandy to the throne of England in the years 1064-66.

What musicheads the playlist in your car or lab? Mozart, Vivaldi and world music, particularly from the Middle East, China and the Andes.

Assuming the dead can be raised and/or time travel exists, with whom from the world outside science would you most like to have dinner?

Jean-François Champollion, who deciphered hieroglyphics using the Rosetta Stone. Although I studied Latin and ancient Greek, I am fascinated by the many ancient languages Champollion knew when he was very young.

Where and when would you most like to have lived or worked?

Now is fine. But I should like to return in several hundred years to see how humans have handled natural resources.

What do you most dislike about having research published?

When a paper appears at the same time as one from a competitor. To be simultaneous is to be too late.

What's the best piece of advice you've received? Be yourself. Don't always follow the trends.

What do you do to relax? (Remember, Nature is a family journal.)

Run for half an hour every morning at sunrise, on a path among ponds with lots of diving and dabbling birds, listening to the tapping noise of woodpeckers.

What would you have become, if not a scientist? A war reporter emphasizing human suffering, or a doctor in the wilderness.

What overlooked or underrated discovery really changed the science in which you work?

Long-term data collection on wildlife, which today is extremely useful for studying the impact of climate change.

Do you have a burning ambition to do or learn something of no practical or immediate value? If so, what?

Like Champollion, to become fluent in ancient languages.

What do you want written on your gravestone? 'Ideas still available for the next three decades'.

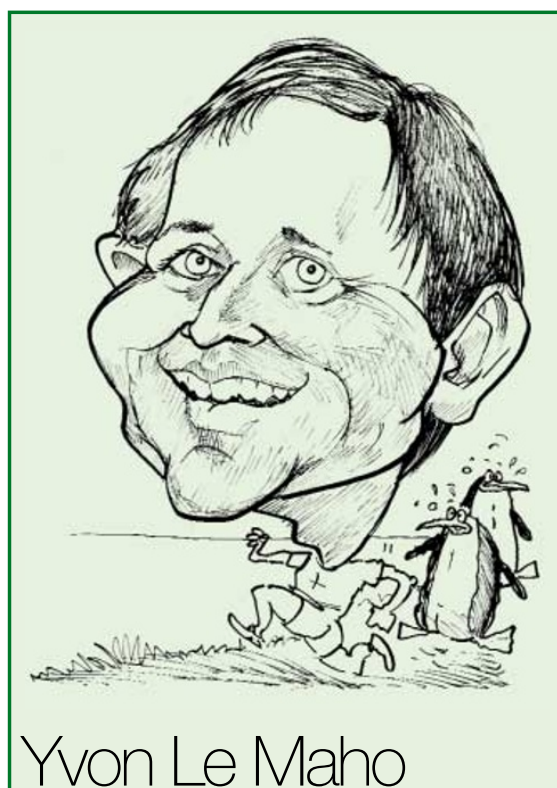

Yvon Le Maho studies how animals adapt to the environment, and is especially fond of penguins. $\mathrm{He}$ is director of the CNRS Centre d'Ecologie et Physiologie Energétiques in Strasbourg, France.

Under what conditions do you have your greatest and most inspired ideas?

On a mountaintop, or contemplating icebergs trapped by winter sea ice.

Is there a 'tyranny of reductionism' in how scientists are trained today?

Reductionist tyranny is not in training, but hidden behind statements such as 'from genes to function' with the agenda that they represent the only route towards integrative biology.

What's the one thing about science that you wish the public understood better?

That scientists aren't always able to give clear-cut answers.

What music would you have played at your funeral?

Gregorian chant, because of its peaceful beauty, and some cantigas of the Medieval Mediterranean, as these religious songs express a joy of life stronger than death.

If you were reborn as a comic-book superhero, what would be your superhuman power? Flying with migrating birds.

You're the only scientist at a party. How do you describe what you do for a living?

I don't describe but I ask simple questions, such as: 'Do you think that there will still be wild fish in the sea next year?'

You've just been told (in confidence) that the world will end tomorrow. What do you do next? You said Nature was a family journal, didn't you...? 